\title{
Ideal harvesting point of 'Limeira-IAC382' trifoliate orange fruits for seed extraction
}

\author{
Patrícia Marluci da Conceição ${ }^{1}$, Fernando Alves de Azevedo ${ }^{2 *}$, Ana Julia Borim de Souza ${ }^{1}$, \\ Alexandre Gonçalves Próspero ${ }^{2}$, Marília Morelli², Victor Augusto Forti ${ }^{1}$ \\ Abstract - Trifoliate orange is one of the rootstocks most used worldwide mainly because it \\ provides excellent quality fruit production. Harvest at the correct time is among factors that \\ determine the physiological quality of seeds. The aim of this study was to identify physicochemical \\ changes in 'Limeira-IAC382' trifoliate orange fruits, searching for the ideal harvest moment to \\ obtain high quality seeds. Fruits were harvested at 180, 210 and 240 days after anthesis, stored \\ in cold chamber and evaluated at $0,15,30$ and 45 days of storage. The following variables were \\ determined: mass loss, fruit color index, soluble solids, total titratable acidity and fruit juice ratio. \\ Seeds were manually extracted and dried until reaching 30\% water content. Seeds were used for \\ the performance of germination, electrical conductivity and greenhouse seedling emergence tests. \\ Seeds from fruits harvested at 240 DAA showed higher germination and greenhouse seedling \\ emergence percentage compared to the other treatments until 30 and 45 days of storage in cold \\ chamber, respectively. Storage for 45 days in cold chamber of fruits harvested at 210 DAA \\ increases seed germination rate and the percentage of seedlings from seeds harvested at 180 DAA. \\ It could be concluded that the harvesting of 'Limeira-IAC382' trifoliate orange fruits should be \\ performed when fruits reached yellowish peel and low juice ratio, aiming at obtaining seeds with \\ physiological quality. \\ Index terms: Poncirus trifoliata (L.) Raf.; rootstock; physiological quality; maturation.

\section{Estádio de maturação ideal para colheita de frutos de trifoliata Limeira-IAC382 visando a extração de sementes}

\section{Corresponding author: fernando@ccsm.br}

Received: August 01, 2019 Accepted: November 01, 2019

Copyright: All the contents of this journal, except where otherwise noted, is licensed under a Creative Commons Attribution License.

\section{(cc) $\mathrm{EY}$}

Resumo - O trifoliata é um dos porta-enxertos de maior uso no mundo, principalmente por proporcionar produção de frutos de excelente qualidade. Dentre os fatores que determinam a qualidade fisiológica das sementes está a colheita de frutos na época correta. Objetivou-se com este trabalho monitorar alterações físico-químicas em frutos de trifoliata Limeira-IAC382, buscando o momento ideal de colheita, visando a obter sementes de qualidade para a produção de bons portaenxertos. Os frutos foram colhidos aos 180;210 e 240 dias após a antese (DAA), armazenados em câmara fria e avaliados aos $0 ; 15 ; 30$ e 45 dias de armazenamento. Foram realizadas as seguintes determinações: perda de massa e índice de cor dos frutos; sólidos solúveis, acidez total titulável e ratio do suco dos frutos. As sementes dos frutos foram extraídas manualmente e secas até atingir $30 \%$ de teor de água. Com as sementes, realizaram-se os testes de germinação, a condutividade elétrica e a emergência em casa de vegetação. As sementes extraídas de frutos colhidos aos 240 DAA apresentam maior porcentagem de germinação e emergência de plântulas, em relação aos demais tratamentos, até 30 dias e 45 dias de armazenamento dos frutos em câmara fria, respectivamente. O armazenamento, por 45 dias em câmara fria, de frutos colhidos aos 210 DAA, aumenta a taxa de germinação das sementes, assim como aumenta a porcentagem de emergência de plântulas de sementes colhidas aos 180 DAA. Conclui-se que a colheita dos frutos de trifoliata Limeira-IAC382 deve ser realizada quando estes apresentarem casca amarelada e baixo valor de ratio do suco, visando obter sementes com qualidade fisiológica.

Termos de indexação: Poncirus trifoliata (L.) Raf.; porta-enxerto; qualidade fisiológica; maturação.

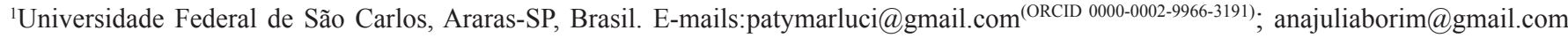
(ORCID 0000-0003-2093-003X); viaugu@yahoo.com.br (ORCID 0000-0003-2599-3603)

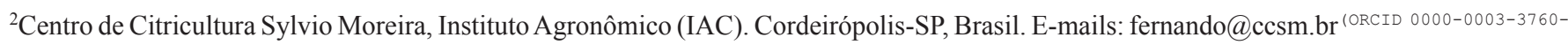
5030); alexandregprospero@gmail.com (ORCID 0000-0002-5544-3162); marilia_morelli@hotmail.com (ORCID 0000-0001-5788-3877)
} 


\section{Introduction}

Citriculture is of great importance in the Brazilian agricultural and economic scenario, being the world's second largest producer of citrus fruits (FAO, 2018). Due to phytosanitary problems that have put pressure on citrus and the advance of production to new areas, the use of healthy and certified seedlings remains an indispensable preventive measure to avoid the occurrence of diseases that have been decimating Brazilian orchards, such as citrus variegated chlorosis (Xylella fastidiosa) and huanglongbing (Candidatus Liberibacter spp.) (BELASQUE JUNIOR et al., 2010).

The demand for quality seeds for citrus rootstock production is growing, as they will generate vigorous plants with conditions to tolerate biotic and abiotic stress situations. In addition, Normative Instruction 48 of September 24, 2013 (MAPA) requires producers to meet the various pre-established parameters. Seeds should be analyzed according to Seed Analysis Rules (BRAZIL, 2009) and can only be marketed based on results of germination or tetrazolium tests, which require minimum of $100 \%$ purity and $50 \%$ germination for marketing (MAPA, 2019).

Seed production stages such as conduction of mother plants, harvesting, processing and storage are of great importance for seed quality (LOLLATO et al., 2007). Determining the ideal harvesting point is mainly aimed at obtaining seeds close to the physiological maturity point, as early harvesting will result in large proportion of immature seeds and delayed harvesting will leave them subject to stressors in the field, thus justifying studies related to seed maturation and harvest (MARCOS FILHO, 2005).

Seed water content and some morphological characteristics, including fruits and plants, have been considered the main reference points for establishing the ideal harvest point. However, these parameters may vary markedly in response to climate fluctuations at the end of the plant cycle. Accurate information is needed, based on simple, fast and consistent identification of the moment when seeds reach physiological maturity (MARCOS FILHO, 2005), which can be obtained by correlating physicochemical characteristics of fruits and germination, as provided for in IN 48 (MAPA, 2019).

For citrus seeds, ideal harvest points are reported for seed quality based on fruit characteristics. The harvesting of citrus rootstock fruits for seed extraction should be performed from the point where the inner part of the fruit (pulp) changes its color to yellow or orange, depending on the species, with fruit peel still being green. For Swingle citrumelo [Poncirus trifoliata (L.) Raf. $\mathrm{x}$ C. paradisi Macfad.)], one should not wait for fruit peel color change, as seeds may germinate within the fruit or have low germination rate (CARVALHO et al., 2005). However, the association between fruit peel color and the physiological quality of seeds is not fully understood, and more information is needed to link fruit color and germination and seed vigor (GOMES-JUNIOR et al., 2017).

Poncirus trifoliata (L.) Raf. rootstock, also known as trifoliate orange, is one of the rootstocks most commonly used in the world's citrus industry, occupying a prominent position in the following countries: Argentina, Australia, United States (California), Japan New Zealand and Uruguay. This preference is due to certain peculiarities induced by this species to the scion / rootstock combinations such as dwarf size, tolerance to Phytophthora root rot, tolerance to sadness virus and nematodes, production of excellent quality fruits, although with low average yield and low drought tolerance (PASSOS et al., 2006).

The aim of this work was to monitor physicochemical changes in 'Limeira-IAC382' trifoliate orange fruits, seeking the ideal harvesting time to obtain seeds with physiological quality to obtain rootstocks.

\section{Material and methods}

\section{Plant material and experimental area}

'Limeira-IAC382' trifoliate orange [Poncirus trifoliata (L.) Raf.] fruits were harvested from three plants belonging to the clonal garden of the 'Sylvio Moreira' Citrus Garden / Agronomic Institute (IAC), located in Cordeirópolis / Sao Paulo State, Brazil (22²7’33’'S, $\left.47^{\circ} 24^{\prime} 17^{\prime} \mathrm{W}\right)$. In the eastern region of the state of São Paulo, the climate is humid temperate with dry winter and hot summer (Köppen-Geiger climate classification: Cwa). Overall, 480 fruits were harvested in three times: 180, 210 and 240 days after anthesis - DAA (Figure 1 A-C), since flowering was identified in the field and branches were marked. In each period, harvested fruits were stored in cold chamber $\left(5 \pm 2{ }^{\circ} \mathrm{C}\right.$ and $85 \pm 3 \%$ relative humidity $)$ and evaluated at $0,15,30$ and 45 days of storage, considering three replicates of 40 fruits for each storage period. Fruits of day ' 0 ' have always been processed within maximum of 24 hours without being submitted to cold chamber.

\section{Physicochemical characterization of fruits}

During storage, fruits were evaluated for: mass loss and fruit color index; soluble solids (SS), total titratable acidity (TTA) and fruit juice ratio (SS / TTA). For mass loss, the initial mass of 20 fruits of each repetition was determined on a digital scale, with maximum capacity of $15 \mathrm{~kg}$ and, subsequently, on each of evaluation dates, mass loss, expressed as percentage, was determined.

Color index was performed on the peel of five fruits per replicate using Minolta model CR 300 digital colorimeter. This measurement was performed at three points in the equatorial region of fruits, calculating the average for the sample. L (luminosity), a (green to red color variation) and $b$ (blue to yellow color variation) values were also determined. $\mathrm{L}$, $\mathrm{a}$ and $\mathrm{b}$ values were used 
to calculate color index with the following formula:

$\mathrm{CI}=(1000 \times \mathrm{a}) /(\mathrm{b} \times \mathrm{L})$.

This index ranges from -20 to +20 (Hunter color scale).

Fruits were crushed in an "Organização Internacional Centenário (OIC)" extractor model OTTO 1800 (filter with internal diameter $=26.11 \mathrm{~mm}$; length $=$ $265 \mathrm{~mm}$; diameter of holes $=0.6 \mathrm{~mm}$; flow area $=20 \%$ ) for juice extraction. Soluble solids content was determined by direct reading in B\&S refractometer model RFM 330 and expressed in ${ }^{\circ}$ Brix, with correction for juice temperature and acidity, which was obtained by titrating $25 \mathrm{~mL}$ of juice with sodium hydroxide solution of 0.3125 normality and phenolphthalein as indicator (REED et al., 1986). The soluble solids / acidity ratio was used as indicator of the ripening stage of citrus fruits.

\section{Physiological quality of seeds}

At each evaluation period during storage, fruits were divided in half by the equatorial region for manual extraction of seeds that were dried in the shade until standardization of their water content in $20 \%$, performed by the stove method (BRAZIL, 2009) at $105 \pm 3^{\circ} \mathrm{C}$ for a period of 24 hours, with two duplicates for each replicate. After drying, seeds were classified as normal and aborted (unfeasible). Once extracted and dried, seeds classified as normal were evaluated for physiological quality through germination, electrical conductivity and seedling emergence tests in greenhouse.

The germination test was performed according to criteria established by the Seed Analysis Rules (BRAZIL, 2009), using as substrate paper roll moistened with water volume equivalent to 2.5 times the dry substrate weight. Thus, two rolls with 50 seeds were made for the three treatment replicates, which were kept in germination chamber at $27^{\circ} \mathrm{C} \pm 1{ }^{\circ} \mathrm{C}$ and evaluated at 30 days after sowing by computing the percentage of normal seedlings for each treatment.

For the electrical conductivity test, the mass method was applied (AOSA, 1983), in which 50 seeds were previously weighed and immersed in $75 \mathrm{~mL}$ distilled water, remaining in BOD incubator at $27 \pm 1^{\circ} \mathrm{C}$ for $24 \mathrm{~h}$. After this period, electrical conductivity was read using conductivity meter. Two evaluations were performed with 50 seeds for each of the three treatment replicates and results were expressed in $\mu \mathrm{S} \mathrm{cm}^{-1} \mathrm{~g}^{-1}$ seed.

To evaluate seedling emergence in greenhouse, seeds were individually placed in tubes filled with pine bark substrates (Plantmax ${ }^{\circledR}$ ) in grooves of $1 \mathrm{~cm}$ in depth. Two trays with 50 tubes were evaluated for each of the three treatment replicates. The substrate was moistened whenever necessary and the final seedling evaluation was performed by stabilizing seedling emergence. Emerged seedlings were those that presented more than $2 \mathrm{~cm}$ of shoot.

\section{Experimental design and data analysis}

The experiment followed a completely randomized design in a $3 \times 4$ factorial scheme, with three harvest periods (180, 210 and 240 days DAA) and four refrigerated storage times $(0,15,30$ and 45 days), with three replicates. Data were submitted to analysis of variance and means compared by the Tukey test at 5\% probability. Storage times were analyzed by regression. Assistat (SILVA; AZEVEDO, 2016) and SigmoPlot 10.0 (Systat Software Inc. San Jose, CA, USA) computer programs were used.

\section{Results and discussion}

\section{Physicochemical characterization of fruits}

During storage in cold chamber, fruits lost mass (Figure 2 A), which may be a result of dehydration, since according to Silva et al. (2000), after harvesting, fruits continue transpiration, losing water, reducing mass and volume. However, mass loss of fruits harvested at 180 DAA was higher than that observed for fruits harvested at 240 DAA (Figure 2 B). According to MEDINA et al. (2005), early harvest fruits have lower amount of wax deposited on the epidermis, which may justify the greater mass loss of fruits harvested at 180 DAA.

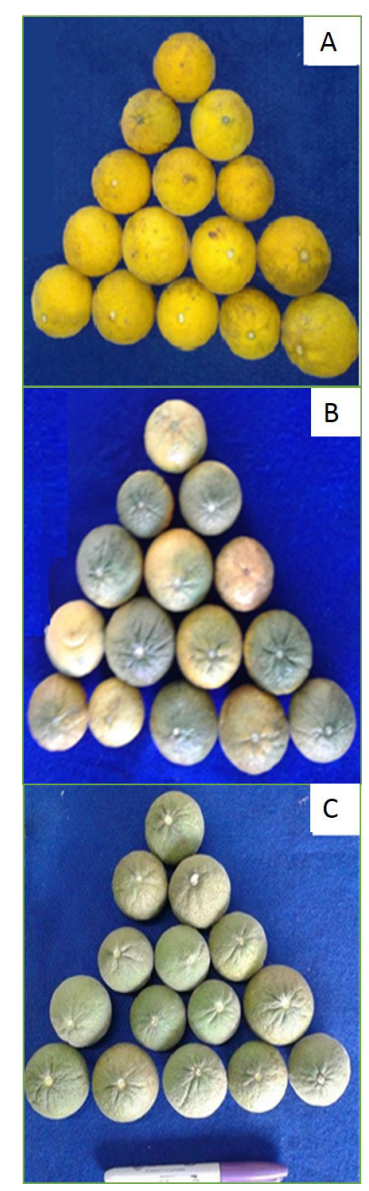

Figure 1. 'Limeira-IAC382' trifoliate orange fruits harvested at different ripening stages: A) 240 days after anthesis (DAA); B) 210 DAA and; C) 180 DAA (Cordeirópolis, Sao Paulo State, Brazil) 

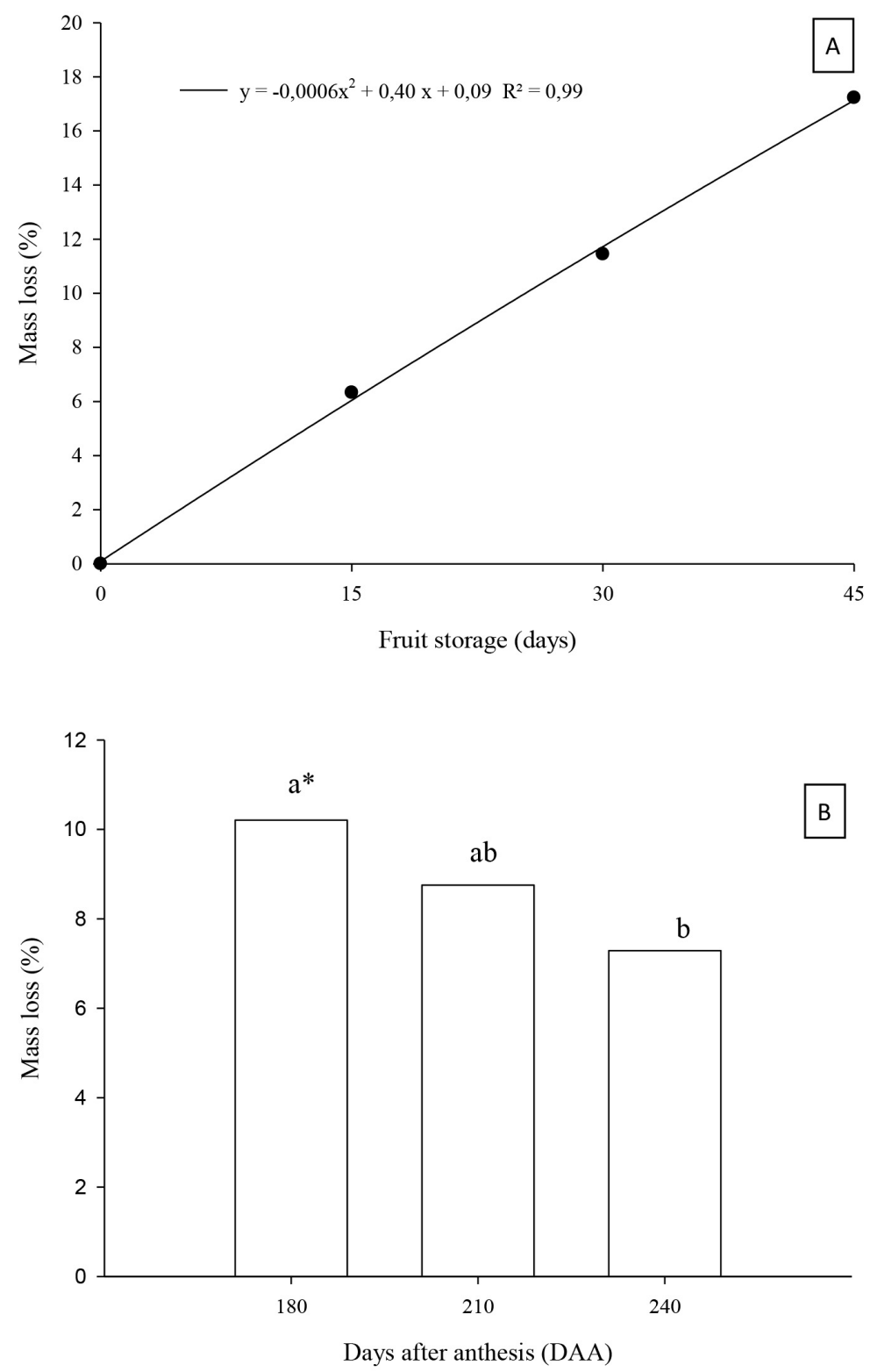

Figure 2. Mass loss (\%) of 'Limeira-IAC382' trifoliate orange [Poncirus trifoliata (L.) Raf.) fruits stored in cold chamber $\left(5 \pm 2^{\circ} \mathrm{C}\right.$ and $85 \pm 3 \%$ relative humidity) for $0,15,30$ and 45 days (A) and harvested at 180,210 and 240 days after anthesis - DAA(B) (Cordeirópolis-SP, 2016/2017). * Means followed by the same letter do not differ statistically from each other by the Tukey test at $5 \%$ probability.

In all harvest periods, an increase in color index (CI) was observed during storage, showing that there was pigmentation of the fruit peel (Figure $3 \mathrm{~A}$ ). Fruits that were initially greenish when harvested at 180 and 210 DAA became more yellowish; however, fruits harvested at 240 DAA were already yellowish $(\mathrm{CI}=0.16)$, which after 45 days of storage became more orange $(\mathrm{CI}=10.5)$. Low temperatures favor the synthesis of carotenoids, responsible for intense yellow and orange color, which may explain the change in fruit peel color (JOMORI et al, 2014).
There was no statistical difference in the amount of soluble solids (SS) of juice among harvest periods, but only with cold storage time (Figure $3 \mathrm{~B}$ ), when a decrease of $21.75 \%$ in SS content was observed after 45 days of storage. The acidity of juice from fruits harvested at 180 DAA was lower than that of fruits harvested at 210 and 240 DAA (Figure 3 C). According to Guardiola (1999), acids accumulate during the initial fruit development and reach maximum content, which values remain constant from then on. The acidity of fruits harvested at 210 and 240 DAA decreased during cold storage. Although citrus fruits are not climacteric due to the virtual absence of ethylene production, respiration rate is accelerated during 
ripening (LIDANIYA, 2008), so after harvest and during storage, the concentration of organic acids tends to decline in most fruits as a result of the use of these compounds as respiratory substrate (KAYS, 1991).

Juice from fruits harvested at 180 DAA and stored up to 30 days presented higher ratio value (soluble solids / acidity) compared to fruits harvested at 210 and 240 DAA (Figure $3 \mathrm{D}$ ). The lower titratable acidity of fruits harvested at 180 DAA promoted higher ratio compared to the other ripening stages. At 45 days of storage, the highest ratio value was observed for fruits harvested at 210 DAA, indicating this treatment as the one with the highest soluble solids accumulation in relation to titratable acidity at 45 days of storage. According to Chitarra and Chitarra (2005), citrus fruits present increase in the SS/ TTA ratio during ripening and storage due to the decrease in acid values and increase in soluble solids. However, the opposite occurred with trifoliate orange fruits, which do not belong to the genus Citrus, but to the related genus Poncirus. This information demonstrates the importance of the present study in characterizing the physicochemical characteristics of rootstock fruits.
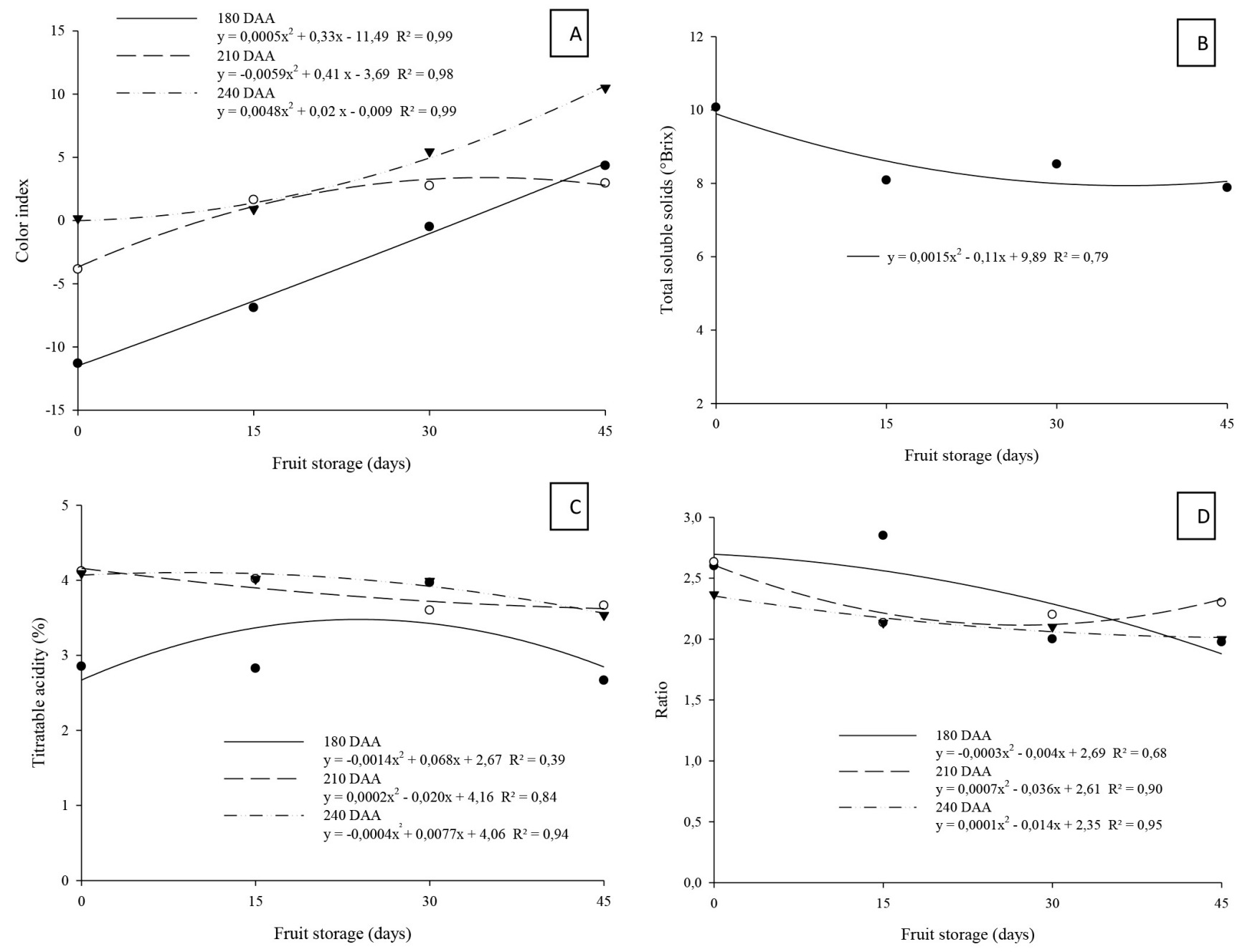

Figure 3. Fruit color index (A), total soluble solids (B), titratable acidity (C) and ratio (D) of 'Limeira-IAC382' trifoliate orange ([Poncirus trifoliata (L.) Raf.) fruits harvested at $180^{\circ} \mathrm{C}, 210$ and 240 days after anthesis (DAA) stored in cold chamber $\left(5 \pm 2^{\circ} \mathrm{C}\right.$ and $\left.85 \pm 3 \% \mathrm{RH}\right)$ for $0,15,30$ and 45 days (Cordeirópolis, 2016/2017). 


\section{Physiological quality of seeds}

Seeds extracted from fruits harvested at 240 DAA presented higher germination, compared to the other treatments up to 30 days of storage, being above the minimum of $50 \%$ determined by IN 48 (MAPA, 2019). There is a marked loss of germination power of these seeds (approximately 40 percentage points) when fruits were stored for 45 days in cold chamber (Figure $3 \mathrm{~A}$ ). Excessive post-harvest storage period of fruits, which varies with species, may result in less germination due to the onset of seed deterioration (RICCI et al., 2013). However, up to 30 days of storage, germination remained above $50 \%$, i.e., according to legislation - IN 48 of 2013 (MAPA, 2019). Thus, seeds could be marketed when extracted from fruits harvested at 240 DAA and stored for up to 30 days.
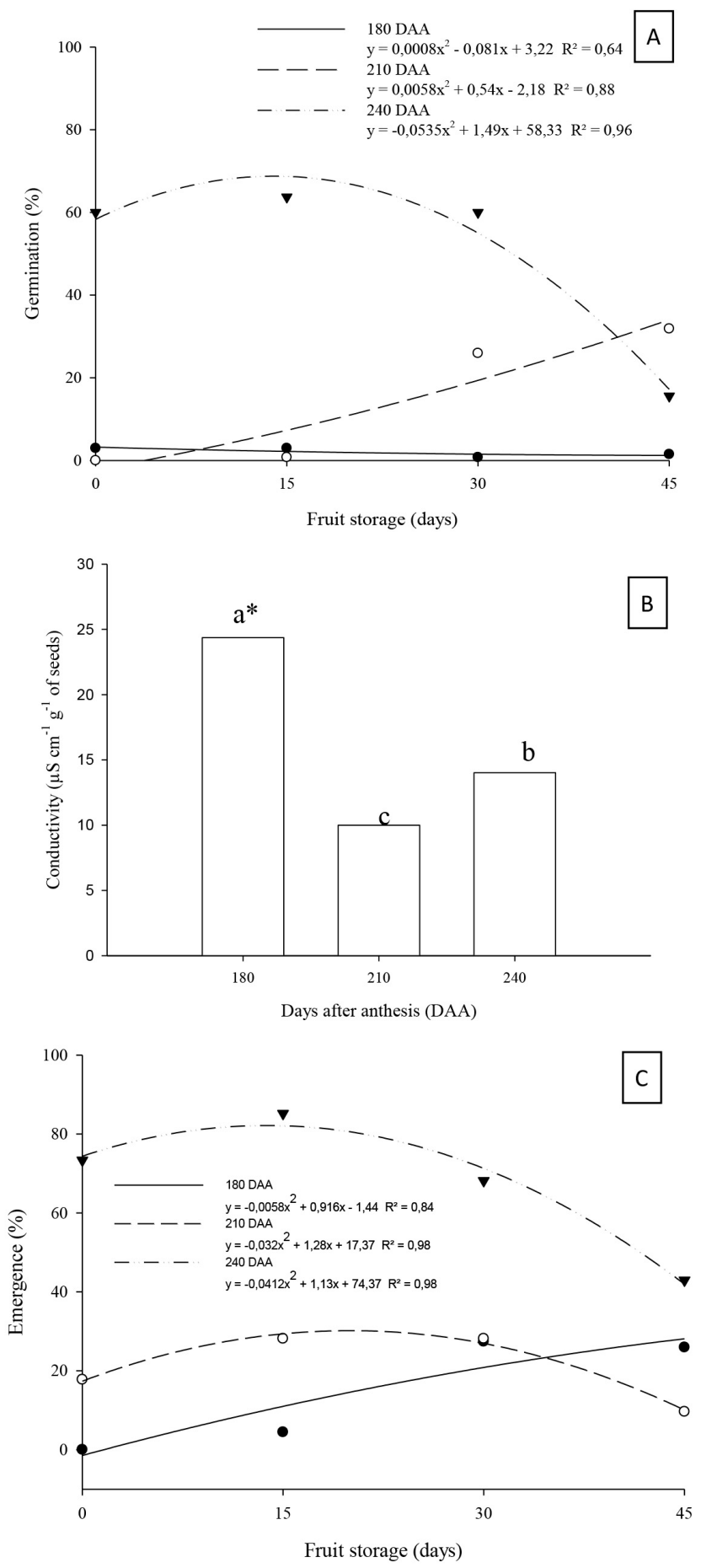

Figure 4. Germination (A), conductivity (B) and emergence (C) of seeds extracted from 'Limeira-IAC382' trifoliate orange [Poncirus trifoliata (L.) Raf.) fruits harvested at 180, 210 and 240 days after anthesis (DAA) stored in cold chamber $\left(5 \pm 2^{\circ} \mathrm{C}\right.$ and $\left.85 \pm 3 \% \mathrm{RH}\right)$ for $0,15,30$ and 45 days (Cordeirópolis, 2016/2017).

* Means followed by the same letter do not differ statistically from each other by the Tukey test at 5\% probability. 
In seeds from fruits harvested at 210 DAA, there was an increase in germination percentage during storage in cold chamber (Figure 4 A), especially after 45 days; however, seeds did not reach minimum values required by legislation. The storage of seeds in fruits may have promoted the overcoming of seed dormancy. Seeds of some citrus rootstock varieties present some type of dormancy, causing germination uniformity problems. Dormancy can be caused by the seed coat, acting as a physical barrier to water imbibition and gas diffusion, or by the presence of an embryo development inhibitor in the seed coat (OLIVEIRA et al., 2006; OLIVEIRA; SCIVITTARO, 2007).

Another possible explanation is that seeds extracted from fruits harvested at 210 DAA were not yet fully formed and finished their formation process still inside the fruit being stored, which is reported for fleshy fruit species (VIDIGAL et al. al., 2006; DIAS et al., 2006). To complete the formation process, the low storage temperature may have influenced the gibberellin (GA) and abcisic acid (ABA) concentrations inside seeds, two phytohormones essential for the occurrence of this physiological event. ABA signaling and synthesis keep the seed in a state of physiological dormancy, and GA signaling determines the point for germination transition. At lower temperatures, ABA levels may decrease and GA levels may increase, favoring the seed germination process (LADO et al., 2016).

For seeds from fruits harvested at 180 days, no germination above $5 \%$ was observed, regardless of fruit storage. Under this condition, seeds may not yet have reached the physiological maturity point and, as a result, are unable to form normal seedling during the experimental period.

The electrical conductivity values of seeds were higher in seeds extracted from fruits harvested at 180 DAA, compared to the other treatments (Figure $4 \mathrm{~B}$ ). Since the electrical conductivity test is based on the electrical resistance modification caused by the leaching of electrolytes from seed tissues to water in which it was immersed (VIDIGAL et al., 2009), the lower electrical conductivity of seeds from fruits harvested at 210 and 240 DAA is related to greater integrity of the seed coat compared to seeds harvested at the beginning of the season. This may indicate that seed coat tissues were not fully formed when fruit was harvested at $180 \mathrm{DAA}$, reaffirming the possibility that they had not yet reached physiological maturity, which also limited their germination.

In seeds from fruits harvested at 240 DAA, there was higher emergence percentage compared to the other treatments (Figure $4 \mathrm{C}$ ). However, the emergence percentage of these seeds decreased after storage for 45 days, a result similar to germination. The emergence of seeds extracted from fruits harvested at 180 DAA increased during cold storage (Figure 4 C). Struiving et al. (2013) also observed loss of vigor of 'Limeira' trifoliate orange seeds, after storing seeds already extracted from fruits of this rootstock, in this case attributed to the reduction of seed water content.

Differences observed between germination and seedling emergence tests in the field may have been a result of the slow germination of this species. The germination test was conducted for only 30 days, while emergence in greenhouse was conducted until the number of plants stabilized, lasting 60 days, on average. According to Chilembwe et al. (1992), the germination of citrus rootstock seeds occurs slowly, so plant development is quite uneven.

Germination percentage and seedling emergence in greenhouse could have been higher in all stages of harvest and fruit storage because in the present work, the seed coat was not removed, which may have impaired seed germination. Carvalho and Silva (2013), Moreira et al. (2010) and Rodrigues et al. (2010) evaluated citrus rootstock seeds ('Swingle' citrumelo and Poncirus trifoliata var. Monstrosa 'Flying Dragon') and observed greater emergence of seed without seed coat, with values above $80 \%$. Seed coat acts as a physical barrier hindering water absorption (OLIVEIRA; SCIVITTARO, 2007), thus delaying the occurrence of chemical reactions that trigger the germination process (RODRIGUES et al., 2010).

Few changes have been observed in the chemical composition of juice from 'Limeira-IAC382' trifoliate orange fruits (Figures $2 \mathrm{~B}, \mathrm{C}$ and D), and the change in peel color was the most evident change between harvest periods and fruit storage. However, in yellowish fruits harvested at 240 DAA, (Figure 3 A), which had higher titratable acidity (Figure $3 \mathrm{C}$ ) and lower mass loss during storage (Figure $2 \mathrm{~B}$ ), seeds presented higher physiological quality with seedling germination and emergence in greenhouse above $60 \%$ (Figures $3 \mathrm{~A}$ and $3 \mathrm{C}$ ), when fruits were stored for up to 30 days. Fruit ripening stage at harvest is one of the main factors affecting the storage potential of citrus seeds (SILVA et al., 2011).

\section{Conclusions}

Seeds extracted from fruits harvested at 240 DAA presented higher germination and emergence percentage, compared to the other treatments up to 30 days of cold storage.

Cold storage for up to 45 days of fruits harvested at 210 DAA increases seed germination rate, but remains below minimum required by law and increases the emergence percentage of seeds harvested at 180 DAA.

It could be concluded that the harvesting of 'Limeira-IAC382' trifoliate orange fruits should be performed when they have yellowish peel $(\mathrm{CI}=0.16)$ and low juice ratio value (2.4), aiming at obtaining seeds with physiological quality, being able to be stored for up to 30 days in cold chamber. 


\section{Acknowledgments}

To FAPESP for granting a scientific initiation scholarship (process: 2014/16548-8) to the second author and for the financial support.

\section{References}

AOSA - Association of Official Seed Analists. Seed vigour testing handbook. Ithaca, 1983. 88p.

BELASQUE JR, J.; YAMAMOTO, P.T.; MIRANDA, M.P.; BASSANEZI, R.B.; AYRES, A.J.; BOVÉ, J.M. . Controle do huanglongbing no estado de São Paulo, Brasil. Citrus Research \& Technology, Cordeirópolis, v. 31, n. 1, p.53-64, 2010.

BRASIL. Ministério da Agricultura, Pecuária e Abastecimento. Secretaria de Defesa Agropecuária. Regras para análise de sementes. Brasília, DF: MAPA/ ACS, 2009. 395p.

CARVALHO, S. A.; GRAF, C. C. D.; VIOLANTE,A. R. Produção de material básico e propagação. In: MATTOS JÚNIOR, D.; DE NEGRI, J.D.; PIO, R.M.; POMPEU JÚNIOR., J. Citros. Campinas: Instituto Agronômico, Fundag, 2005. p. 279-316.

CARVALHO, S.A.; SILVA, L.F.C. Monitoring the viability of citrus rootstocks seeds stored under refrigeration. Revista Brasileira de Fruticultura, Jaboticabal, v.35, n.1, p.238-245, 2013.

CHILEMBWE, E.H.C.; CASTLE, W.S.; CANTLIFFE, D.J. Grading, hydrating and osmotically priming seed of four citrus rootstocks to increase germination rate and seedling uniformity. Journal of the American Society for Horticultural Science, Alexandria, v.117, n.3, p.368$372,1992$.

CHITARRA, M.I.F.; CHITARRA, A.B.. Pós-colheita de frutas e hortaliças: fisiologia e manuseio. 2. ed. Lavras: Universidade Federal de Lavras, 2005. p.785.

DIAS, D.C.F.S.; RIBEIRO, F.P.; DIAS, L.A.S.; SILVA, D.H.; VIDIGAL. D.S. Tomato seed quality in relation to fruit maturation and post-harvest storage. Seed Science and Technology, Zürich, v.34, n.3, p.691-699, 2006.
FAO - Food and Agriculture Organization of United Nations. FAOSTAT. Rome, 2018. Disponível em: faostat. fao.org. Acesso em: 10 ago. 2018.

GOMES-JUNIOR, F.G.; ARRUDA, N.; MARCOS FILHO, J. Swingle citrumelo seed vigor and storability associated with fruit maturity classes based on RGB parameters. Scientia Agricola, Piracicaba, v.74, n.5, p.357-363, 2017.

GUARDIOLA, J.L. Componentes nutritivos de la naranja. In: FUNDACIÓN VALENCIANA DE ESTUDIOS AVANZADOS. (ed.). Naranja y salud. Valencia, 1999. p.143-162.

JOMORI, M.L.L.; SASAKI, F.F.C.; BERNO, N.D.; GIMENES,LCL.; KLUGE, R.A. Desverdecimento e armazenamento refrigerado de tangor 'Murcott' em função de concentração e tempo de exposição ao etileno. Semina: Ciências Agrárias, Londrina, v.35, n.2, p.825834, 2014.

KAYS, S.J. Postharvest physiology of perishable plant products. New York: Van Nostrand Reinhold, 1991. 532p.

LADO J.; SAINZ, M.M.; ZACARIAS, L.; MANZI, M.; SOTELO, M. Involvement of plant hormones in cold stress tolerance. In: AHAMMED G. J.; YU J.Q. Plant hormones under challenging environmental factors. Berlin: Springer, 2016. p.23-49.

LIDANIYA, M. S. Citrus fruit: biology, technology and evolution. San Diego: Academic Press, 2008. p. 1-558.

LOLLATO, M.A.; SHIOGA, P.S.; PÓLA, J.N.; BARROS, A.S.R.; MOTA, C.A.P.; KRZYZANOWSKI, F.C. Produção no campo e processamento de sementes. In: BARROS, A.S.R. (coord.). Produção de sementes em pequenas propriedades. 2.ed. Londrina: Instituto Agronômico do Paraná, 2007. p.12-42.

MAPA - Ministério da Agricultura Pecuária e Abastecimento. Instrução normativa $n^{\circ} \mathbf{4 8}$, de 24 de setembro de 2013. Brasília, 2013. Disponível em: $\leq$ www.lex.com.br/legis 24871657 INSTRUCAO NORMATIVA N 48 DE 24 DE SETEMBRO DE 2013.aspx>. Acesso em: 26 fev de 2019.

MARCOS FILHO, J. Fisiologia de plantas cultivadas. Piracicaba: Fealq, 2005. 495p. 
MEDINA, C.L.; MACHADO, E.C.; RENA, A.B.; SIQUEIRA, D.L. de. Fisiologia dos citros. In: MATTOS JUNIOR, D.; NEGRI J. D.; PIO M. R.; POMPEU JUNIOR, J. Citros. Campinas: Instituto Agronômico e Fundag, 2005. p.147-195.

MOREIRA, R.A.; RAMOS, J.D.; CRUZ, M.C.M. Caracterização de frutos e poliembrionia em sementes de 'Flying Dragon' e de híbridos de porta-enxerto de citros. Revista Brasileira de Fruticultura, Jaboticabal, v.32, n.2, p.486-492, 2010.

OLIVEIRA, R.P.; SCITITTARO, W.B.; RADMANN, E.B. Escarificação química da semente para favorecer a emergência e o crescimento do porta-enxerto Trifoliata. Pesquisa Agropecuária Brasileira, Brasília, DF, v.41, n.9, p.1429-1433, 2006.

OLIVEIRA, R.P.; SCIVITTARO, W.B. Formação do porta-enxerto Trifoliata: época de semeadura e tegumento na emergência de plântulas. Ciência Rural, Santa Maria v.37, n.1, p.281-283, 2007.

PASSOS, O.S.; PEIXOUTO, L.S.; SANTOS, L.C.; CALDAS, R.C.; SOARES FILHO, W. Caracterização de híbridos de poncirus trifoliata e de outros porta-enxertos de citros no estado da Bahia. Revista Brasileira de Fruticultura, Jaboticabal, v.28, n.3, p.410-413, 2006.

REED, J,B.; HENDRIX, J.R.C.M.; HENDRIX, D.L. Quality control manual for citrus processing plants. Safety Harbour: Intercit, 1986. v.1, 250p.

RICCI, N.; PACHECO, A.C.; CONDE, A.S.; CUSTODIO, C.C. Qualidade de sementes de pimenta jalapenho em função da maturação e tempo de permanência nos frutos. Pesquisa Agropecuária Tropical, Goiânia, v.43, n.3, p.123-129, 2013.
RODRIGUES, F.A.; FREITAS, G.F.; MOREIRA, R.A.; PASQUAL, M.. Caracterização dos frutos e germinação de sementes dos porta-enxertos Trifoliata Flying Dragon e citrumelo Swingle. Revista Brasileira de Fruticultura, Jaboticabal, v.32, n.4, p.1180- 1188, 2010.

SILVA, F. A. S.; AZEVEDO, C. A. V. The Assistat Software Version 7.7 and its use in the analysis of experimental data. African Journal of Agricultural Research, v. 11, n. 39, p. 3733-3740, 2016.

SILVA, J.S.; FINGER, F.L.; CORRÊA, P.C. Armazenamento de frutas e hortaliças. In: SILVA, J.S. (org.). Secagem e armazenagem de produtos agrícolas. Viçosa: Aprenda Fácil, 2000. p.469-502.

SILVA, T.T.A.; GUIMARÃES, R.M.; PINHO, E.V.R.; ABREU, L.A.S. Storage of 'Swingle' citrumelo seeds in different maturation stages subjected to fungicide treatment. Revista Brasileira de Sementes, Londrina, v.33, n.4, p.768-776, 2011.

STRUIVING, T.B.; MACHADO, D.L.M.; SANTOS, D.; SIQUEIRA, D.L.; LUCENA, C.C.; MATARAZZO, P.H.M. Qualidade fisiológica de sementes de citros durante o armazenamento em ambiente refrigerado. Ciência Rural, Santa Maria, v.43, n.10, p.1777-1782, 2013.

VIDIGAL, D.S.; DIAS, D.C.FS.; PINHO, E.V.R.; DIAS, L.A.S. Alterações fisiológicas e enzimáticas durante a maturação de sementes de pimenta (Capsicum annuum L.). Revista Brasileira de Sementes, Londrina, v.31, n. 2, p.129-136, 2009.

VIDIGAL, D.S.; DIAS, D.C.F.S.; NAVEIRA, D.S.P.; ROCHA, F.B.; BHERING, M.C. Qualidade fisiológica de sementes de tomate em função da idade e do armazenamento pós-colheita dos frutos. Revista Brasileira de Sementes, Londrina, v.28, n.3, p.87-93, 2006. 